\title{
Influence of Driving Direction on the Stability of a Group of Headings Located in a Field of High Horizontal Stresses in the Polish Underground Copper Mines ${ }^{+}$
}

\author{
Karolina Adach-Pawelus * (D) and Daniel Pawelus \\ Faculty of Geoengineering, Mining and Geology, Wroclaw University of Science and Technology, \\ 50-370 Wroclaw, Poland; daniel.pawelus@pwr.edu.pl \\ * Correspondence: karolina.adach@pwr.edu.pl \\ † This paper is an extended version of the paper published in 2018 World Multidisciplinary Earth Sciences \\ Symposium, Prague, Czech Republic, 3-7 September 2018, 012097.
}

check for updates

Citation: Adach-Pawelus, K.; Pawelus, D. Influence of Driving Direction on the Stability of a Group of Headings Located in a Field of High Horizontal Stresses in the Polish Underground Copper Mines. Energies 2021, 14, 5955. https://doi.org/ 10.3390/en14185955

Academic Editors: Sergey Zhironkin and Dawid Szurgacz

Received: 5 August 2021

Accepted: 16 September 2021

Published: 19 September 2021

Publisher's Note: MDPI stays neutral with regard to jurisdictional claims in published maps and institutional affiliations.

Copyright: (c) 2021 by the authors. Licensee MDPI, Basel, Switzerland. This article is an open access article distributed under the terms and conditions of the Creative Commons Attribution (CC BY) license (https:// creativecommons.org/licenses/by/ $4.0 /)$.
Abstract: This paper investigates the problem of stability in a group of headings driven in high horizontal stress fields in the copper ore mines of the Legnica-Glogow Copper Belt (LGCB). The headings are protected with the roof bolting system. This problem is of high importance due to special safety regulations which apply in mining workings serving as airways and haulageways. The analysis was performed for a group of four headings driven in the geological and mining conditions of the Polkowice-Sieroszowice mine. The stability of the headings was evaluated with the use of Finite Element Method (FEM). The parameters of the rocks used in the numerical modeling have been determined on the basis of the Hoek-Brown classification, with the use of the RocLab 1.0 software. The parameters of the stress field have been identified on the basis of in situ measurements, which were performed in the Polkowice-Sieroszowice mine in 2012. The measurements were carried out with the use of the overcoring method, which is a stress relief method. A CSIRO HI probe was used as the measuring device. The tests were carried out on three measuring points, on which six successful tests were performed. The measurements confirmed the presence of high horizontal stresses in the rock mass. Numerical modeling was performed using the Phase2 v.8.0 software, in a triaxial stress state and in a plane strain state. The rock mass was described with an elastic-plastic model with softening. Numerical analyses were based on the Mohr-Coulomb failure criterion. It was assumed that the optimal measure of the stability of the group of headings is the range of the formed zone of yielded rock mass in the excavation roof. Numerical simulations have shown that the direction of driving the headings in the field of increased horizontal stresses may be of key importance for the stability of the headings in LGOM mines. The greatest extent of the yielded rock mass zone in the excavation roof occurred when the group of headings was driven in the direction perpendicular to the direction of the maximum horizontal stress component $\sigma_{H}$. The obtained results served to provide an example of the application of a roof bolting system to protect headings driven in unfavorable conditions in a high horizontal stress field.

Keywords: numerical modeling; high horizontal stress; excavations stability assessment

\section{Introduction}

Numerous observations and measurements performed both worldwide [1-13] and in Poland [14-16] suggest that in many cases the value of primary horizontal stresses is significantly greater than the values accepted to date, which are based solely on the Poisson's ratio $v$. Another observation also indicated that the maximum component of the horizontal stresses in the rock mass was frequently up to several times higher than the vertical component. Therefore, primary stresses in the rocks forming the Earth's crust are believed to result from the accumulation of gravitational and tectonic stress fields [17], and the intensity of horizontal stresses is the function of 
- interaction of individual tectonic units,

- the terrain surface,

- tectonic features of the rock mass,

- depth of the rock mass, and

- stiffness of rock material, expressed, among others through Poisson's ratio $v$ and the modulus of linear deformation (longitudinal modulus of elasticity) $E$.

Research conducted by many scientists shows that high horizontal stress has a significant impact on underground excavations stability [9,18-21].

In a number of mines worldwide, some of the cases in which the stability of a heading was lost (Figure 1) or some phenomena having an impact observed in the heading were caused by an inadequate knowledge of the extents and directions of horizontal stresses in the mined rock mass [2,4-7]. The direction in which a heading is driven and in which horizontal stresses propagate was also observed to influence the stability of the heading (Figure 2). In the most advantageous scenario, the direction of the maximum increased horizontal stress component is parallel to the longer axis of symmetry of the heading. In such case, the heading does not lose its stability due to horizontal stresses (Figure 2a). In the case when the heading is driven at an angle to the direction of the maximum horizontal stress component, the roof may suffer damage, and the floor may become uplifted at the left or right wall (Figure $2 b, c)$. When the direction of the maximum component is perpendicular to the direction in which the heading is driven, the least advantageous scenario occurs and the heading loses its stability (Figure $2 \mathrm{~d}$ ). In the central part of the heading, the roof collapses and the floor is uplifted [22].

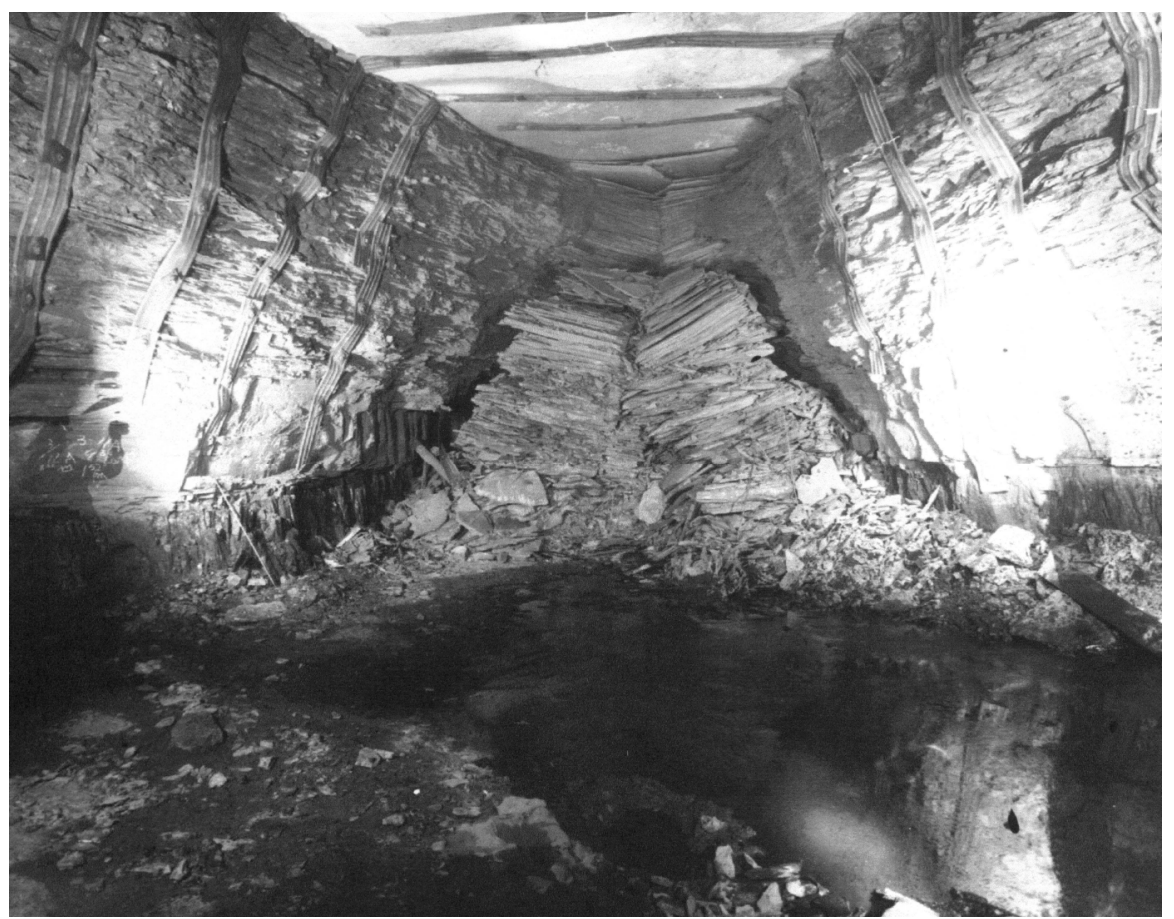

Figure 1. Collapse of immediate roof due to increased horizontal stresses in the Beckley mine [7]. 


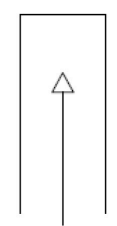

undisturbed roof

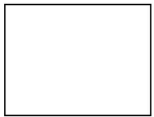

undisturbed floor b

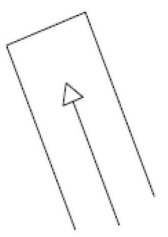

destruction of the roof on the left side

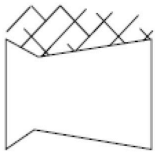

possible floor uplift on the left side

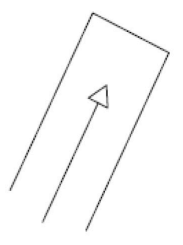

destruction of the roof on the right side

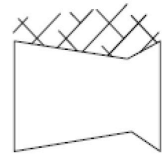

possible floor uplift on the right side d

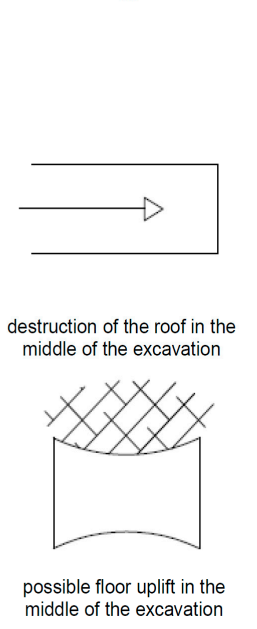

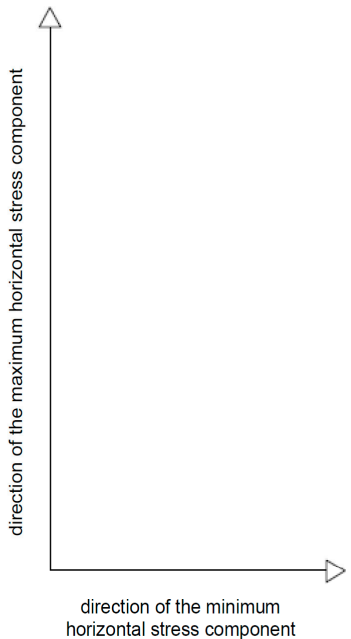

Figure 2. Influence of horizontal stress on heading stability (based on the works in [3,23]). (a) undisturbed floor; (b) possible floor uplift on the left side; (c) possible floor uplift on the right side; (d) possible floor uplift in the middle of the excavation.

In Polish underground mines, no efforts are made towards identifying the directions and values of primary horizontal stresses in the rock mass for the purpose of designing optimal heading systems and heading support structures. Roof bolting is the most commonly used roof support system in Polish copper mines of the Legnica-Glogow Copper Belt (LGCB) region. Prior to the choice of a support type for a mining excavation, roof class is determined in accordance with the "Instructions on determining the geomechanical parameters of roof rocks with respect to roof classes in copper mines", as required in the selection of a roof bolting system design [24]. The classification of roof rocks (from class 1-the worst, to class 5-the best) is based on such parameters as

- roof bedding (vertical split),

- concentration of mineralized foigs,

- fault concentration,

- average fault throw, and

- tensile strength of the roof rock beam.

The roof bolting system is selected after identifying the roof class and in accordance with the "Regulations on the selection, construction and control of excavation support in the KGHM Polska Miedz S.A. mines" [25]. The roofs in the headings are protected with bolts at least $1.6 \mathrm{~m}$ long. The distance between the bolts (the rock bolt pattern) is adjusted depending on the class of the roof and on the width of the heading below the roof. Supports are also installed on the heading walls. The wall bolts have a length of at least $1.6 \mathrm{~m}$ and are spaced in the side walls at $1.5 \times 1.5 \mathrm{~m}$. The lower row of the bolts is situated at a distance of approximately $1.8 \mathrm{~m}$ from the floor. The side walls are provided with a support system if

- excavation height is greater than $4.5 \mathrm{~m}$ (regardless of the inclination angle of the side walls) or

- excavation height is not greater than $4.5 \mathrm{~m}$ and moving the side walls outwards by approximately $10^{\circ}$ is not possible.

As copper ore extraction depth in the LGCB region has exceeded the depth of $1200 \mathrm{~m}$ below ground level. and is performed in increasingly difficult geological and mining conditions, the copper ore mines in the region may suffer from a growing number of problems related to the stability of excavations located in the field of high horizontal stresses. Therefore, further extensive research needed to be performed into the directions and values of main stresses in the mines operated by KGHM Polska Miedz S.A. The next step should involve a research program which would allow identifying the influence of the directions 
and values of high horizontal stresses on the stability of mining excavations supported with roof bolting systems and located at a depth below $1200 \mathrm{~m}$ below ground level.

Numerical methods significantly expand research possibilities related to the analysis and evaluation of the stability of excavations and their support systems in underground mines. Numerical modeling gives the possibility to predict the stress concentration zones and the potential locations in which the rock mass may become unstable in the vicinity of a mining excavation. The numerical, FEM-based computer analyses performed to date on the stability of mining excavations have demonstrated the influence of horizontal stress direction on the stability of excavations in the LGCB mines $[22,26]$.

This research, which focuses on the influence of the direction in which headings are driven in the "Polkowice-Sieroszowice" mine in the presence of high horizontal stress fields, is a continuation and development of research performed as part of a program titled "Implementation of numerical methods in the analysis of selected natural hazards in underground mines". This research was performed between 2017 and 2018 at the Mining Division, Wroclaw University of Science and Technology. Some results of this research were presented in scientific conferences and published [26,27]. Further research is needed however, as the results of numerical simulations may be used to plan and design inter alia access, preparatory and production excavations of various shapes and dimensions, as well as to aid the choice of adequate primary and secondary support systems. It is of special importance for the copper ore extraction operations performed in the area of the LGCB at depths exceeding $1200 \mathrm{~m}$ below ground level.

\section{In-Situ Tests of Stresses in the Polkowice-Sieroszowice Mine}

In 2012, the LGCB copper ore mines (the Rudna mine and the Polkowice-Sieroszowice mine) were the sites of a test program - the most extensive program in the history of Polish mining industry-aimed at in situ examinations of stresses in the rock mass. The measurements were conducted as part of a research project entitled "Determination of the impact of the primary stress directions and magnitudes on the optimal geometry of mining fields" [16]. The measurements were performed by a team consisting of the employees of KGHM Cuprum Ltd. R\&D Center, the Rudna mine and Golder Associates Ltd. The aim of the measurements was to identify the distribution of primary stresses in the regions planned for operation within the Glogow Gleboki-Przemyslowy mining area. The analysis of the progress of the access and preparatory works indicated that the measurement points should be located in the northern and north-western parts of the Polkowice-Sieroszowice mine. Eventually, three locations for the measurement points were identified:

- measurement point 1: located in the "Sieroszowice I" mine area, between crosscuts 13 and 12 in main haulage roadway T-360, at a depth of $966.0 \mathrm{~m}$ below ground level;

- measurement point 2: located in division G-62, in main haulage roadway T-357, in the vicinity of crosscut P-84; and

- measurement point 3: located in the "Sieroszowice I" mine area, in the recess of main incline E-1, in the vicinity of crosscut 63, at a depth of $906.0 \mathrm{~m}$ below ground level.

The in situ measurements in the Polkowice-Sieroszowice mine were performed with the use of the overcoring method, which is a stress relief method. The method consists in cutting a rock sample from the rock mass in which a high horizontal stress field is observed and in simultaneously measuring the strain or displacement due to stress relief in the sample [28]. The stages of the overcoring method are shown in Figure 3. The most important of them are

- boring a hole in the rock which has a large-diameter $(60-220 \mathrm{~mm})$ and a length sufficient to treat the influence of the mining excavation as negligible (Figure 3a),

- driving a pilot hole typically $38 \mathrm{~mm}$ in diameter (Figure $3 \mathrm{~b}$ ),

- placing a measurement device (probe) in the pilot hole, and

- effecting stress relief in the cut-out cylinder, whose deformations are recorded with a measurement device (Figure 3c). 
a

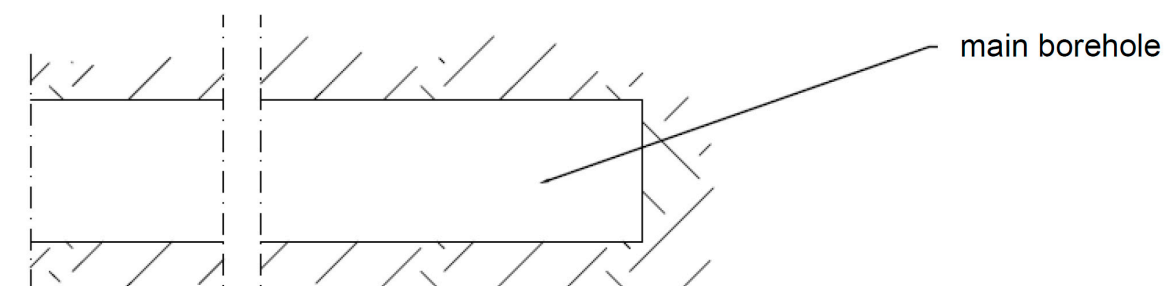

b

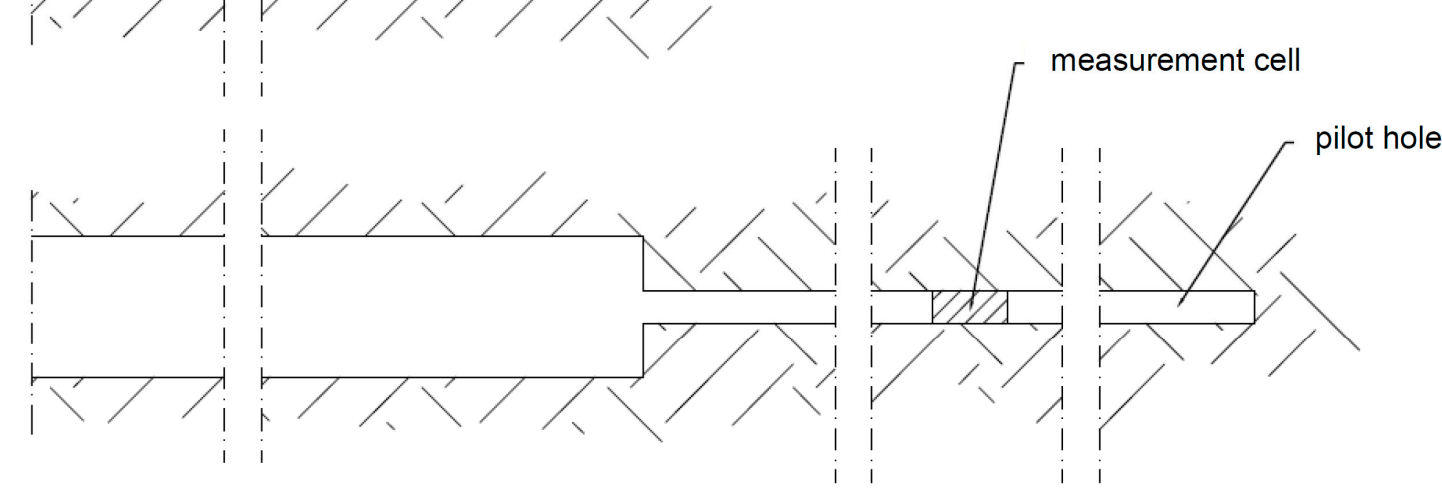

C
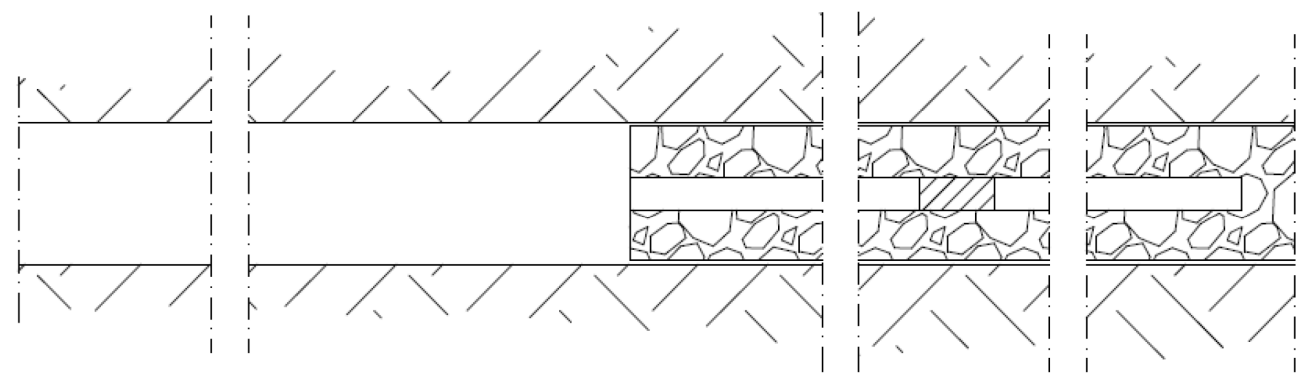

Figure 3. Stages of the overcoring method. (a) boring a hole in the rock which has a large-diameter (60-220 $\mathrm{mm})$ and a length sufficient to treat the influence of the mining excavation as negligible; (b) driving a pilot hole typically $38 \mathrm{~mm}$ in diameter and placing a measurement device (probe) in the pilot hole; (c) effecting stress relief in the cut-out cylinder, whose deformations are recorded with a measurement device.

The stress tensor components in the rock mass are calculated from the values of strain measured during the process of relieving the sample in the vicinity of the measurement device. After the measurement, the rock sample is recovered for laboratory testing in order to determine Poisson's coefficient $v$ and longitudinal modulus of elasticity E. Examinations also include visual inspection of the measuring cell and the surrounding rock, as well as the quality of the adhesive bond and the degree of rock disturbance [28].

The measurement device used in the Polkowice-Sieroszowice mine was a CSIRO HI test probe (Figure 4). It has 12 independent strain gauges glued in an arrangement of three "rosettes", three gauges in each "rosette", and three gauges glued circumferentially. Owing to the above, a single measurement provides a sufficient amount of data and allows the components of the stress tensor in the three-axis system to be fully determined. The probe is secured in the borehole with a special adhesive of known deformation parameters. The disadvantages of the overcoring measurements with the use of the CSIRO HI probe include the sensitivity to loose rock fragments in the borehole which hinder correct insertion of the probe, as well as thermal effects generated during the drilling process and the presence of water in the borehole $[16,28]$. The obtained results allowed determining horizontal stress distribution in the rock mass for the Polkowice-Sieroszowice mine (Table 1). 


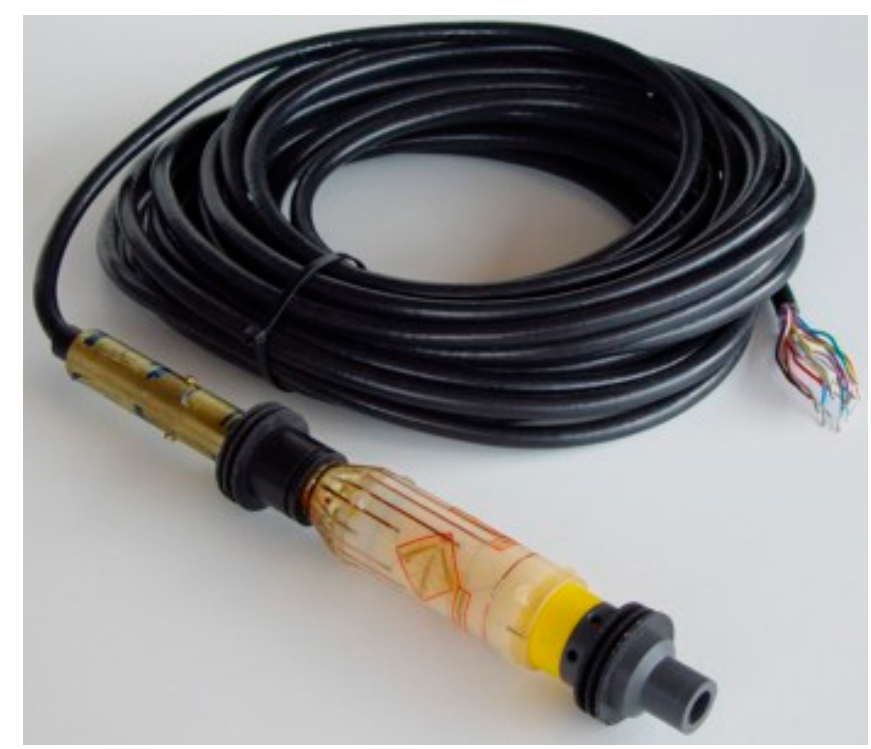

Figure 4. CSIRO HI test probe.

Table 1. Parameters of horizontal stress fields at the Polkowice-Sieroszowice mine $[16,26]$.

\begin{tabular}{cccccc}
\hline \multirow{2}{*}{ Measurement Test No. } & \multicolumn{5}{c}{ Stress Field Parameters } \\
\cline { 2 - 5 } & $\sigma_{H}[\mathbf{M P a}]$ & $\alpha_{H}\left[^{\circ}\right]$ & $\sigma_{h}[\mathbf{M P a}]$ & $\alpha_{h}\left[^{\circ}{ }^{\circ}\right.$ & $\sigma_{v}[\mathbf{M P a}]$ \\
\hline SP1T2 & 29.9 & 160.0 & 22.3 & 70.0 & 27.7 \\
SP1T3 & 29.9 & 157.0 & 24.4 & 67.0 & 27.9 \\
SP1T4 & 20.6 & 158.0 & 16.9 & 68.0 & 22.7 \\
SP2T2 & 32.2 & 6.0 & 26.1 & 96.0 & 27.7 \\
SP3T2 & 27.7 & 156.0 & 14.5 & 66.0 & 27.6 \\
SP3T3 & 19.2 & 139.0 & 12.8 & 49.0 & 18.2 \\
\hline
\end{tabular}

The symbols used in the above table are as follows: $\sigma_{H}$-maximum component of horizontal stress, $\alpha_{H}$-azimuth of the maximum horizontal stress component, $\sigma_{h}$-minimum component of horizontal stress, $\alpha_{h}$-azimuth of the minimum horizontal stress component, $\sigma_{v}$-vertical stress.

\section{Stability Prediction for a Group of Headings at the Polkowice-Sieroszowice Mine}

The influence of high horizontal stresses on the stability of headings in the PolkowiceSieroszowice mine was modeled with the use of the Phase2 v. 8.0 software (Rocscience, Toronto, ON, Canada). This computer application is based on Finite Element Method (FEM). In FEM, a solution to a typical problem is searched for in the following stages:

- dividing an area into subareas,

- determining FEM equations for the elements,

- gluing (aggregating) the elements,

- allowing for boundary conditions,

- solving the equations, and

- calculating additional values in other (than nodes) points of the area [22].

The parameters of the rocks used in the numerical modeling are shown in Table 2. The parameters were determined from the geomechanical tests of rock samples. Rock samples for laboratory tests were obtained from the Jm-06 To- 1 borehole, which is located in the Sieroszowice I mining area, division G-62, at the crossing of main incline E- 1 and crosscut 33 . The analysis of the data obtained from the Jm-06 To- 1 borehole indicated that the rock mass represents a geological structure typical for the Fore Sudetic Monocline in which the access and preparatory excavations of the Polkowice-Sieroszowice mine are driven. The immediate roof is built of carbonate formations (Calcareous dolomite II) having high strength and strain parameters. The rocks forming the mined deposit height and the formations in the floor have various values of strength and strain parameters. 
Table 2. Mean strength and strain rock parameters determined in laboratory tests for the Jm-06 To-1 borehole [26].

\begin{tabular}{cccccccc}
\hline Location & Rock Type & $\begin{array}{c}\boldsymbol{h} \\
{[\mathbf{m}]}\end{array}$ & $\begin{array}{c}\boldsymbol{\rho} \\
{\left[\mathbf{k g} / \mathbf{d m}^{3}\right]}\end{array}$ & $\begin{array}{c}\boldsymbol{R}_{\boldsymbol{c}} \\
{[\mathbf{M P a}]}\end{array}$ & $\begin{array}{c}\boldsymbol{R}_{\boldsymbol{r}} \\
{[\mathbf{M P a}]}\end{array}$ & $\begin{array}{c}\boldsymbol{E}_{\boldsymbol{i}} \\
{[\mathrm{GPa}]}\end{array}$ & $\begin{array}{c}\boldsymbol{v} \\
{[-]}\end{array}$ \\
\hline \multirow{2}{*}{ Roof } & Anhydrite & 16.00 & 2.94 & 92.16 & 6.69 & 53.22 & 0.26 \\
& Calcareous dolomite II & 9.00 & 2.82 & 236.10 & 14.59 & 113.17 & 0.25 \\
& Calcareous dolomite I & 0.50 & 2.47 & 98.43 & 6.04 & 38.77 & 0.26 \\
& Streaky dolomite & 0.90 & 2.77 & 140.57 & 9.33 & 40.73 & 0.24 \\
Excavation & Clay dolomite & 0.55 & 2.63 & 79.50 & 5.70 & 28.75 & 0.23 \\
& Quartz sandstone IV & 0.25 & 2.40 & 39.97 & 2.78 & 16.53 & 0.19 \\
& Quartz sandstone III & 0.30 & 2.25 & 16.57 & 0.80 & 7.23 & 0.13 \\
& Quartz sandstone II & 3.90 & 2.07 & 20.67 & 1.22 & 8.63 & 0.14 \\
& Quartz sandstone I & 1.10 & 2.02 & 16.95 & 0.75 & 6.65 & 0.12 \\
\hline
\end{tabular}

The Hoek-Brown failure criterion, which is broadly used in geomechanical analyses of rock mass deformations and effort, was assumed for the rock mass. The generalized Hoek-Brown failure criterion for a fractured rock mass may be described with the following equation [29]:

$$
\sigma_{1}=\sigma_{3}+\sigma_{c i} \cdot\left(m_{b} \cdot \frac{\sigma_{3}}{\sigma_{c i}}+s\right)^{a}
$$

where

$\sigma_{1}$ and $\sigma_{3}$-values of the maximum and minimum principal effective stress at failure, $m_{b}$ - the Hoek-Brown constant for the rock mass,

$s$ and $a$-constants depending on the rock mass properties,

$\sigma_{c i}$-the uniaxial compressive strength of the rock sample.

When rock mass tensile strength $\sigma_{t m}$ is exceeded, the equation for $a=0.5$ can be formulated as follows:

$$
\sigma_{t m}=\frac{\sigma_{c i}}{2} \cdot\left(m_{b}-\sqrt{m_{b}^{2}+4 s}\right) .
$$

After the failure criterion was assumed, the following rock mass parameters have been determined for each of the rock layers obtained from the Jm-06 To-1 borehole (Table 3):

- uniaxial tensile strength of the rock mass $\sigma_{t}$,

- $\operatorname{cohesion} c$,

- internal friction angle $\varphi$, and

- rock mass modulus of elasticity $E_{r m}$.

Table 3. Rock mass parameters determined with the RocLab 1.0 application the Jm-06 To-1 measurement borehole [26].

\begin{tabular}{cccccc}
\hline Location & Rock Type & $\begin{array}{c}\sigma_{t} \\
{[\mathbf{M P a}]}\end{array}$ & $\begin{array}{c}c \\
{[\mathbf{M P a}]}\end{array}$ & $\begin{array}{c}\boldsymbol{\phi} \\
{\left[{ }^{\circ}\right]}\end{array}$ & $\begin{array}{c}\boldsymbol{E}_{\boldsymbol{r m}} \\
{[\mathbf{M P a}]}\end{array}$ \\
\hline \multirow{2}{*}{ Roof } & Anhydrite & 0.738 & 6.896 & 38.66 & $39,000.37$ \\
& Calcareous dolomite II & 5.226 & 21.535 & 39.00 & $99,628.96$ \\
& Calcareous dolomite I & 1.495 & 7.853 & 37.69 & $31,649.89$ \\
\multirow{5}{*}{ Excavation } & Streaky dolomite & 3.112 & 12.821 & 39.00 & $35,856.57$ \\
& Clay dolomite & 0.828 & 5.653 & 36.31 & $21,068.41$ \\
& Quartz sandstone IV & 0.103 & 2.784 & 39.06 & 8595.60 \\
& Quartz sandstone III & 0.043 & 1.154 & 39.06 & 3759.60 \\
& Quartz sandstone II & 0.053 & 1.439 & 39.06 & 4487.60 \\
& Quartz sandstone I & 0.044 & 1.180 & 39.06 & 3458.00 \\
\hline \multirow{2}{*}{ Floor } & & & & &
\end{tabular}

The calculations were performed with the use of the RocLab 1.0 software, which employs the Hoek-Brown classification [29-32].

Numerical modeling was performed using the Phase 2 v. 8.0, in a triaxial stress state and in plane strain state. Numerical simulations were performed for an isotropic and for 
a uniform medium. The rock medium was described with an elastic-plastic model with softening. The strength-strain parameters of the rocks in the model are shown in Table 4. The numerical modeling was performed on the basis of the Mohr-Coulomb failure criterion, which states that rock may reach threshold effort if the following condition is met:

$$
\sigma_{1}=\sigma_{3} \cdot \frac{1+\sin \varphi}{1-\sin \varphi}+\frac{2 c \cos \varphi}{1-\sin \varphi}
$$

or

$$
\sigma_{3}=-\sigma_{t}
$$

where

$\sigma_{1}$ and $\sigma_{3}$-effective maximum and minimum stress at failure,

$\phi$-internal friction angle,

$c$-cohesion, and

$\sigma_{t}$-uniaxial tensile strength of the rock mass.

\begin{tabular}{|c|c|c|c|c|c|c|c|c|c|c|}
\hline Location & Rock Type & $\begin{array}{c}h \\
{[\mathrm{~m}]}\end{array}$ & $\begin{array}{c}E_{s} \\
{[\mathrm{MPa}]}\end{array}$ & $\begin{array}{c}v \\
{[-]}\end{array}$ & $\begin{array}{c}\sigma_{t} \\
{[\mathrm{MPa}]}\end{array}$ & $\begin{array}{c}\phi_{\text {peak }} \\
{\left[{ }^{\circ}\right]}\end{array}$ & $\begin{array}{c}c_{p e a k} \\
{[\mathrm{MPa}]}\end{array}$ & $\begin{array}{c}\phi_{d y l} \\
{\left[{ }^{\circ}\right]}\end{array}$ & $\begin{array}{c}\phi_{\text {resid }} \\
{\left[{ }^{\circ}\right]}\end{array}$ & $\begin{array}{c}c_{\text {resid }} \\
{[\mathrm{MPa}]}\end{array}$ \\
\hline \multirow{2}{*}{ Roof } & Anhydrite & 16.00 & $39,000.37$ & 0.26 & 0.738 & 38.66 & 6.896 & 2.00 & 36.73 & 1.379 \\
\hline & Calcareous dolomite II & 9.00 & $99,628.96$ & 0.25 & 5.226 & 39.00 & 21.535 & 2.00 & 37.05 & 4.307 \\
\hline $\begin{array}{l}\text { Excavation } \\
(h=3.5 \mathrm{~m})\end{array}$ & $\begin{array}{l}\text { Deposit mined in } \\
\text { dolomite-sandstone }\end{array}$ & 2.50 & $25,184.11$ & 0.22 & 1.617 & 38.16 & 7.847 & 2.00 & 36.25 & 1.569 \\
\hline \multirow{2}{*}{ Floor } & Quartz sandstone II & 3.90 & 4487.60 & 0.14 & 0.053 & 39.06 & 1.439 & 2.00 & 37.11 & 0.288 \\
\hline & Quartz sandstone I & 1.10 & 3458.00 & 0.12 & 0.044 & 39.06 & 1.180 & 2.00 & 37.11 & 0.236 \\
\hline
\end{tabular}

Table 4. Rock mass parameters adopted for the elastic-plastic numerical model with softening.

The numerical analyses were performed for a group of four headings. The excavations have a trapezoidal shape. The inclination angle of the side walls was assumed at $10^{\circ}$. The roof was identified to be class four [24] and was protected with bolts $1.6 \mathrm{~m}$ in length with the bolting pattern $1.5 \times 1.5 \mathrm{~m}$ [25]. Table 5 contains the dimensions of headings in the assumed cross-sections.

Table 5. Dimensions of the analyzed headings.

\begin{tabular}{cccccc}
\hline $\begin{array}{c}\text { Excavation Height } \\
h[\mathrm{~m}]\end{array}$ & $\begin{array}{c}\text { Excavation Width } \\
\text { Below the Roof } \\
\boldsymbol{d}_{w s t}[\mathrm{~m}]\end{array}$ & $\begin{array}{c}\text { Excavation Width } \\
\text { at the Floor } \\
\boldsymbol{d}_{w s p}[\mathrm{~m}]\end{array}$ & $\begin{array}{c}\text { Mean Excavation } \\
\text { Width } \\
\boldsymbol{d}_{w s r}[\mathrm{~m}]\end{array}$ & $\begin{array}{c}\text { Excavation } \\
\text { Surface Area } \\
S_{r}\left[\mathrm{~m}^{2}\right]\end{array}$ & $\begin{array}{c}\text { Side Wall } \\
\text { Inclination Angle } \\
\boldsymbol{\alpha}\left[{ }^{\circ}\right]\end{array}$ \\
\hline 3.5 & 7.0 & 5.8 & 6.4 & 22.4 & 10.0 \\
\hline
\end{tabular}

The numerical model was based on the values of primary stresses recorded in the Polkowice-Sieroszowice mine, at measurement point 2 (Table 1, measurement number SP2T2). Two variants of loads acting on the group of headings were assumed for the numerical calculations. The flat, rectangular plate comprising four openings (located inside and shaped to correspond to the shapes of the analyzed excavations) was loaded on its edges:

- $\quad$ load variant 1 (maximum horizontal stress component $\sigma_{H}$ is in the direction parallel to the longer axis of the headings):

- side edges: $p_{x}=26.10 \mathrm{MPa}$,

- upper edge and bottom edge: $p_{z}=27.70 \mathrm{MPa}$,

- direction perpendicular to plate surface: $p_{y}=32.20 \mathrm{MPa}$,

- load variant 2 (maximum horizontal stress component $\sigma_{H}$ is in the direction perpendicular to the longer axis of the headings): 
- side edges: $p_{x}=32.20 \mathrm{MPa}$,

- upper edge and bottom edge: $p_{z}=27.70 \mathrm{MPa}$,

- direction perpendicular to plate surface: $p_{y}=26.10 \mathrm{MPa}$.

The edges of the analyzed plate were equipped with supports which do not slide either in the vertical or in the horizontal direction. The numerical analysis employed finite elements having three nodes and triangular shape. The plate edges were assumed to be at a $100.0 \mathrm{~m}$ distance from the extreme points on each side of the analyzed headings (the roof, the floor and the side walls). In the middle of the plate, in the location the headings, smaller size finite elements were used (finite element grid density region) in order to increase the accuracy of numerical calculations. Based on the numerical calculations of heading stability for each model (calculation variant), the following parameters were determined:

- distribution of principal stresses $\sigma_{1}$,

- distribution of principal stresses $\sigma_{3}$,

- horizontal stress distribution $\sigma_{x x}$,

- vertical stress distribution $\sigma_{\mathrm{yy}}$,

- total displacements,

- yielded element area (yielded rock mass zone).

The analysis of the results indicated that the optimal measure of the stability of the group of headings is the range of the yielded rock mass zone in the roof of the heading.

\section{Results of Numerical Simulations and Selection of the Bolting System}

The numerical models of the stability of headings located in the field of high horizontal stresses in the Polkowice-Sieroszowice mine confirmed the results obtained in previous research $[22,26]$. The numerical simulations demonstrated among other things that

- the direction in which headings are driven in a field of high horizontal stresses may be of key importance to the stability of headings in the LGCB mines, and

- problems with stability may occur when the yielded rock zone in the roof is larger than the bolted zone.

Figures 5-8 show the maximum range of yielded rock mass (between $50 \%$ and $100 \%$ ) in the roofs of the headings. In the case of a group of headings driven parallel to the direction of the maximum horizontal stress component $\sigma_{H}$ (load variant 1$)$, the maximum range was $1.36 \mathrm{~m}$ (Figure 7 ). At the same time, the maximum range of yielded rock mass in the roofs of the headings driven in perpendicular to the direction of the maximum horizontal stress component $\sigma_{H}$ (load variant 2) was greater by $0.58 \mathrm{~m}$ and reached $1.94 \mathrm{~m}$ (Figure 8). The numerical calculations also demonstrated that:

- The surface of the relaxed area around a heading increases together with the increase of the horizontal stress in the rock mass (high stress field in the rock mass). Meanwhile, stress concentration in the analyzed headings occurs only in the corners of the roofs and of the side walls.

- The greatest total displacements occur in the floors of the analyzed headings (formed of sandstones having low strength and strain parameters). The range of the zone affected by displacements increases together with the increase of horizontal stresses in the rock mass.

- The surface of the yielded area in the rock mass around headings driven in the heading group increases together with the increase of horizontal stresses in the rock mass (high stress field in the rock mass). This phenomenon is strictly related to the stress and strain parameters of the rock layers surrounding the excavations and negatively influences their stability.

- The verification of the results of the numerical simulations obtained for the plasticelastic model with rock softening confirmed that they correspond most accurately to the observed cases of stability losses in the mining excavations of Polish copper mines. 


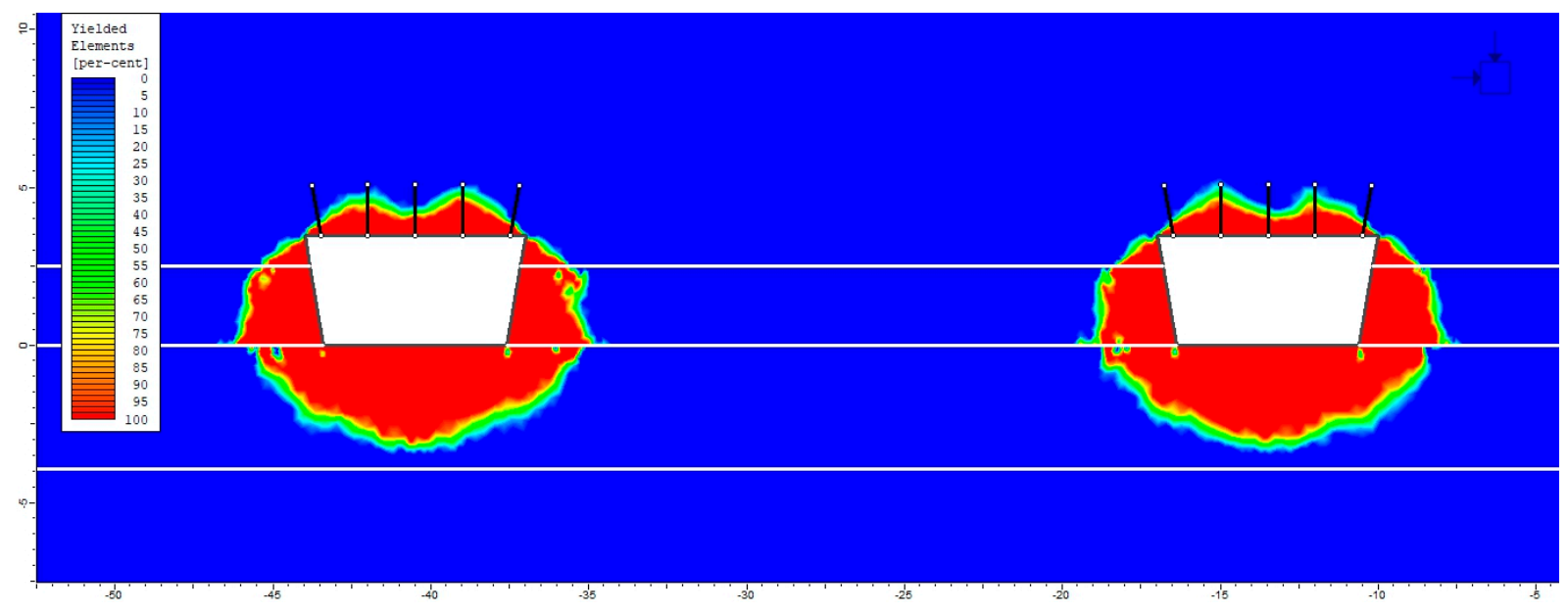

Figure 5. Yielded element area around heading 1 and heading 2, load variant 1.

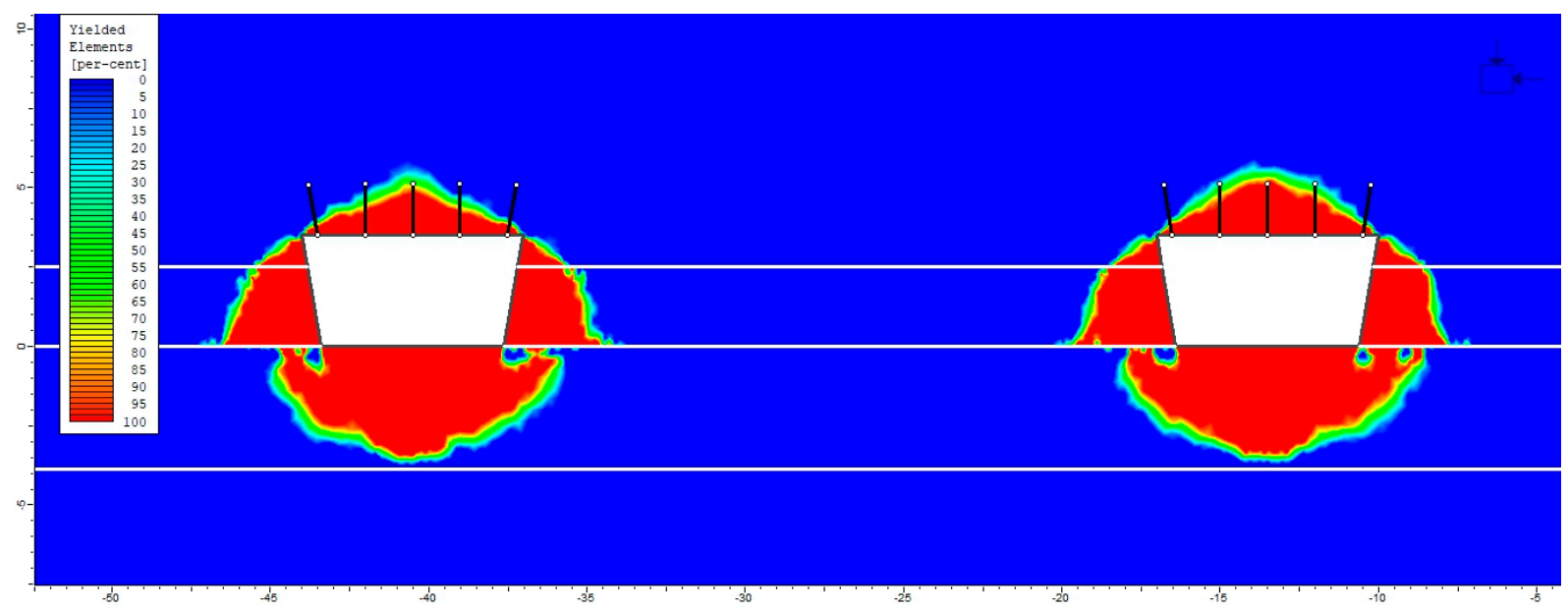

Figure 6. Yielded element area around heading 1 and heading 2, load variant 2.

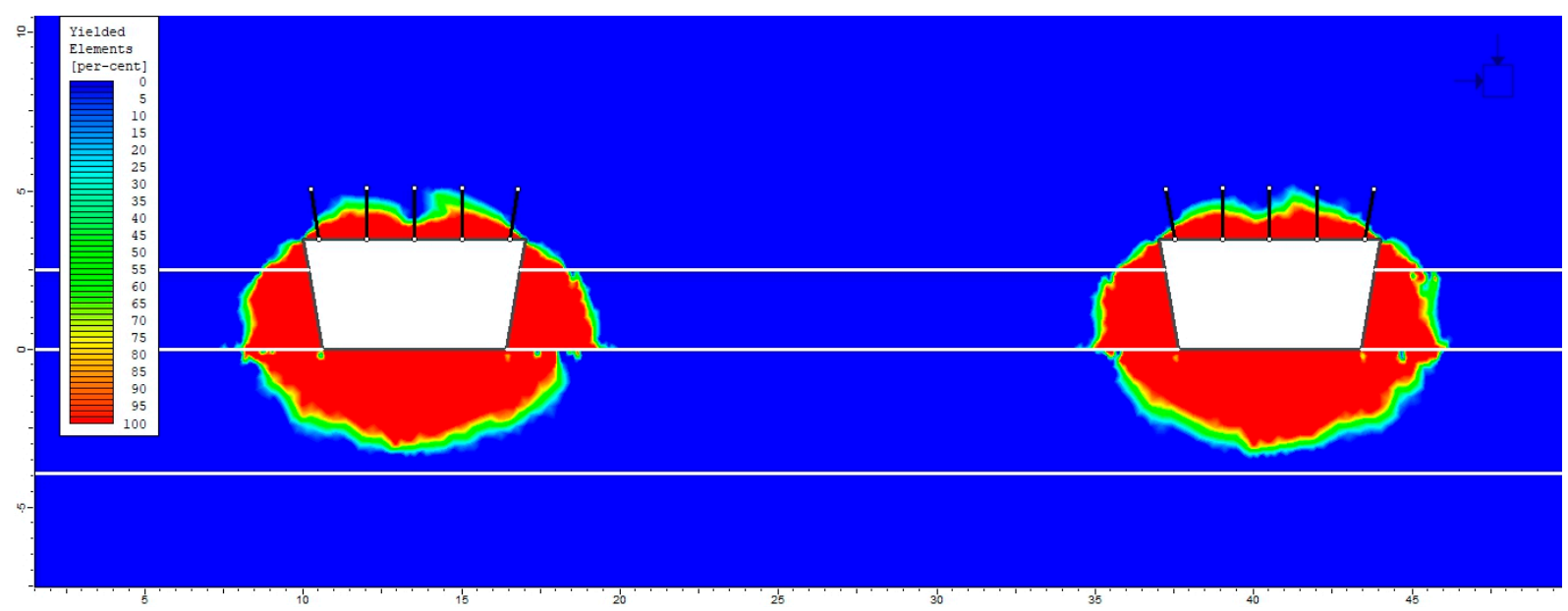

Figure 7. Yielded element area around heading 3 and heading 4, load variant 1 . 


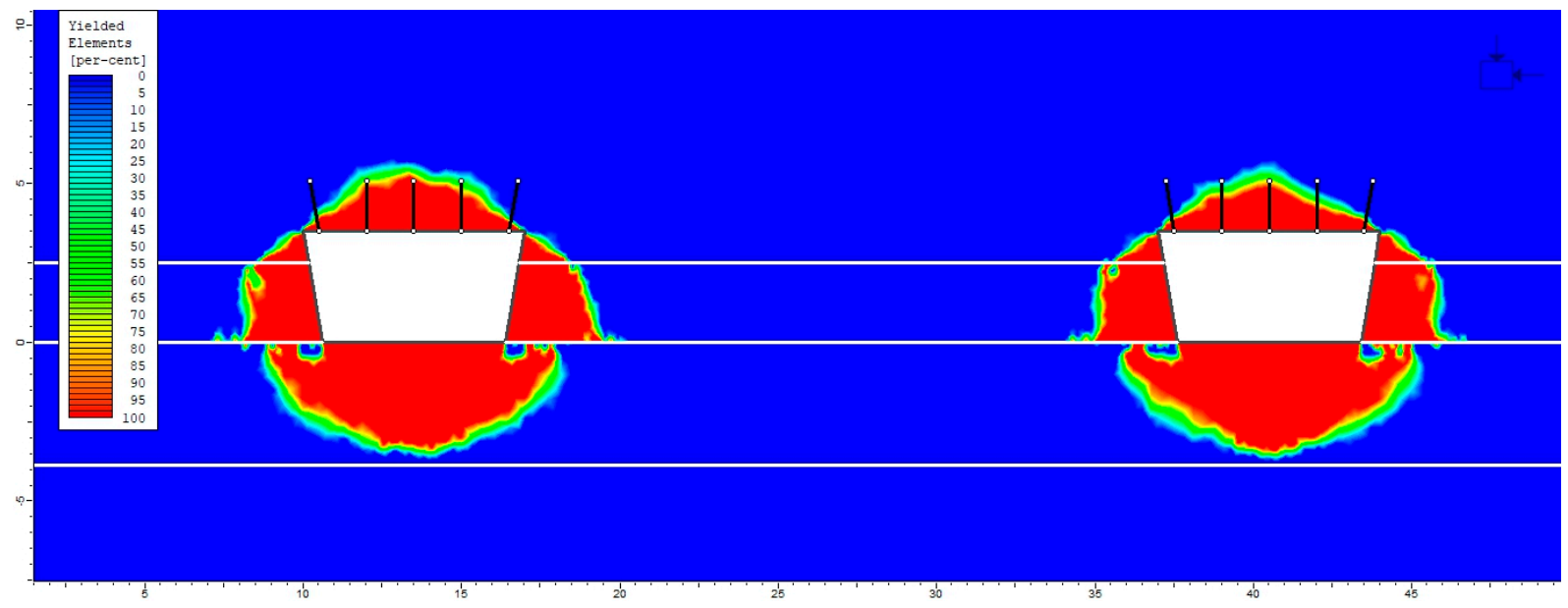

Figure 8. Yielded element area around heading 3 and heading 4, load variant 2.

Table 6 lists the range of yielded rock mass (yield between 50\% and 100\%) in the roofs of the analyzed headings. For the assumed geological and mining conditions of the Polkowice-Sieroszowice mine, the simulated change of direction in which the heading group is driven resulted in an increased yielded zone in the roofs within the range of $0.45 \div 0.58 \mathrm{~m}$, which translates into an increase by $34.09 \%$ to $42.65 \%$, respectively. The maximum range of yielded rock mass in the roofs of the headings driven in perpendicular to the direction of the maximum horizontal stress component $\sigma_{H}$ (load variant 2) was greater than the bolted zone of $1.6 \mathrm{~m}$. The excavations may suffer from the loss of roof stability (collapse of the immediate roof in the excavation).

Table 6. List of the yielded rock mass range in the roofs of the analyzed headings (yield between 50\% and $100 \%)$.

\begin{tabular}{ccccc}
\hline \multirow{2}{*}{ Excavation } & \multicolumn{2}{c}{ Yield Range in the Roof [m] } & Increase of Yield Range in the Roof \\
\cline { 2 - 5 } & Load Variant 1 & Load Variant 2 & [m] & {$[\%]$} \\
\hline 1 & 1.32 & 1.77 & 0.45 & 34.09 \\
2 & 1.34 & 1.91 & 0.57 & 42.54 \\
3 & 1.36 & 1.94 & 0.58 & 42.65 \\
4 & 1.30 & 1.76 & 0.46 & 35.38 \\
\hline
\end{tabular}

The numerical modeling allowed an optimal selection of the roof bolting system design for a group of headings located in the field of high horizontal stresses. The support system was based on resin-grouted bolts, which are intended to protect the excavation over the entire period if its operation. Depending on the direction in which the heading group is driven, the following bolt lengths and positions were selected:

- $\quad$ in the case of a group of headings driven parallel to the direction of the maximum horizontal stress component $\sigma_{H}$, the bolts were $1.6 \mathrm{~m}$ in length and the bolting pattern (distance between the bolts) was $1.5 \times 1.5 \mathrm{~m}$,

- $\quad$ and in the case of a group of headings driven perpendicular to the direction of the maximum horizontal stress component $\sigma_{H}$, the bolts were $2.2 \mathrm{~m}$ in length and the bolting pattern (distance between the bolts) was $1.5 \times 1.5 \mathrm{~m}$,

The simulations were based on an assumption that the bolted zone in the roof must be larger by at least $0.5 \mathrm{~m}$ than the maximum range of the $100 \%$ yielded zone.

\section{Conclusions}

Some observed cases of stability loss in mining excavations are caused by a lack of knowledge about the size and direction in which horizontal stresses act in the mined rock mass. The in situ measurements and the numerical simulations confirmed that the driving 
direction of a heading and the directions of horizontal stresses affect heading stability in the geological and mining conditions of the Polkowice-Sieroszowice mine.

The stability of headings depends the direction in which they are driven in a field of high horizontal stresses, in relation to the direction of the maximum horizontal stress component $\sigma_{H}$ in the rock mass. Therefore, this parameter should be given appropriate consideration in the process of selecting an optimal roof support system for a heading. The additional parameters which influence heading stability include: the shape of the heading, its cross section surface area (heading width under the roof), heading depth (the value of stresses in the rock mass), and the stress and strain parameters of the rocks surrounding the heading.

An accurate recognition of the stress field in the mining area allows the development of optimal preventive methods. Numerical methods prove very useful in such tasks, as they allow broad and extensive analyses of heading stability. The in situ observations of actual stability loss cases in the LGCB copper ore mines and the numerical simulations of heading stability fully confirm the need to use numerical modelling in preparing designs of mining excavations and of their support systems.

Author Contributions: Conceptualization, D.P.; methodology, K.A.-P. and D.P.; software, D.P.; validation, D.P.; formal analysis, K.A.-P.; investigation, D.P.; resources, D.P.; data curation, D.P.; writing—original draft preparation, K.A.-P. and D.P.; writing—review and editing, K.A.-P.; visualization, D.P.; supervision, D.P.; project administration, K.A.-P. and D.P.; funding acquisition, K.A.-P. All authors have read and agreed to the published version of the manuscript.

Funding: The research work was co-founded with the research subsidy of the Polish Ministry of Science and Higher Education granted for 2021.

Institutional Review Board Statement: Not applicable.

Informed Consent Statement: Not applicable.

Data Availability Statement: The data presented in this study are available on request from the corresponding author.

Conflicts of Interest: The author declares no conflict of interest.

\section{References}

1. Hast, N. The state of stresses in the upper part of the earth's crust. Eng. Geol. 1967, 2, 5-17. [CrossRef]

2. Mark, C. Horizontal stress and its effects on longwall ground control. Min. Eng. 1991, 11, 1356-1360.

3. Daws, G.; Hons, B. Roof bolting in coal mining-Design and implementation. Min. News 1992, 1, 27-32. (In Polish)

4. Mark, C.; Mucho, T.P. Longwall Mine Design for Control of Horizontal Stress, New Technology for Longwall Ground Control; US Government Printing Office: Washington, DC, USA, 1994; pp. 53-73.

5. Mark, C.; Mucho, T.P.; Dolinar, D. Horizontal stress and longwall headgate ground control. Min. Eng. 1998, 61-68.

6. Mark, C. Focus on Ground Control: Horizontal Stress. Coal Age 2001, 106, 47-50.

7. Agapito, J.; Gilbride, L. Horizontal stresses as indicators of roof stability. In Proceedings of the SME Annual Meeting, Phoenix, AZ, USA, 25-27 February 2002.

8. Heidbach, O.; Tingay, M.; Barth, A.; Reinecker, J.; Kurfeß, D.; Müller, B. Global stress pattern based on the World Stress Map database release. Tectonophysics 2008, 482, 3-15. [CrossRef]

9. Trinh, N.; Jonsson, K. Design considerations for an underground room in a hard rock subjected to a high horizontal stress field at Rana Gruber, Norway. Tunn. Undergr. Space Technol. 2013, 38, 205-212. [CrossRef]

10. Zhaoa, X.G.; Wanga, J.; Caib, M.; Maa, L.K.; Zonga, Z.H.; Wanga, X.Y.; Sua, R.W.; Chena, M.; Zhaoa, H.G.; Chenc, Q.C.; et al. In-situ stress measurements and regional stress field assessment of the Beishan area, China. Eng. Geol. 2013, 163, 26-40. [CrossRef]

11. Haghi, A.H.; Kharrat, R.; Asef, M.R. A case study for HCL-based fracturing and stress determination: A Deformation/Diffusion/Thermal approach. J. Petrol. Sci. Eng. 2013, 112, 105-116. [CrossRef]

12. Haghi, A.H.; Chalaturnyk, R.; Ghobadi, H. The state of stress in SW Iran and implications for hydraulic fracturing of a naturally fractured carbonate reservoir. Int. J. Rock. Mech. Min. Sci. 2018, 105, 28-43. [CrossRef]

13. Salmachi, A.; Rajabi, M.; Wainman, C.; Mackie, S.; McCabe, P.; Camac, B.; Clarkson, C. History, Geology, In Situ Stress Pattern, Gas Content and Permeability of Coal Seam Gas Basins in Australia: A Review. Energies 2021, 14, 2651. [CrossRef]

14. Fabjanczyk, M.; Bryja, Z.; Bugajski, W.; Katulski, A. Measurement of pre-exploitation stress field in KGHM Polska Miedz, O/ZG Rudna. Proc. Undergr. Min. School 1997, 1, 67-75. (In Polish) 
15. Fabich, S.; Lis, J.; Pytel, W.; Szadkowski, T.; Szlazak, M. Calculation of Stress in Rock Mass in Various Geological and Mining Conditions on the Basis of In-Situ Measurements, Stage I: Development of Technologies Allowing the Measurement of Primary and Production Stress Tensor in the Rock Mass, and Completing the First Stage of Measurements; Cuprum R\&D Centre: Wroclaw, Poland, 2003. (In Polish)

16. Butra, J. (Ed.) Magnitude and Directions of In-Situ Stress in the Deep Part of a Copper ore Deposit with an Appendix "Determination of the Impact of the Primary Stress Directions and Magnitudes on the Optimal Geometry of Mining Fields; KGHM Cuprum sp. z o.o. R\&D Centre: Wroclaw, Poland, 2012. (In Polish)

17. Kidybiński, A. Basics of Mining Geotechnics; Slask: Katowice, Poland, 1982.

18. Ming, J.; Hongjun, G. Influence of in-situ rock stress on the stability of roadway surrounding rock: A case study. J. Geophys. Eng. 2020, 17, 138-147. [CrossRef]

19. Esterhuizen, G.S.; Dolinar, D.R.; Iannacchione, A. Field observations and numerical studies of horizontal stress effects on roof stability in US limestone mines. J. S. Afr. Inst. Min. Metall. 2008, 108, 345-352.

20. Abdel-Meguid, M.; Rowe, R.K.; Lo, K.Y. Three-dimensional analysis of unlined tunnels in rock subjected to high horizontal stress. Can. Geotech. J. 2003, 40, 6. [CrossRef]

21. Li, H.; Lin, B.; Hong, Y.; Gao, Y.; Yang, W.; Liu, T.; Wang, R.; Huang, Z. Effects of in-situ stress on the stability of a roadway excavated through a coal seam. Intern. J. Min. Sci. Technol. 2017, 27, 917-927. [CrossRef]

22. Pawelus, D. Influence of Horizontal Stress on the Stability of Underground Excavations in Copper Mines. Ph.D. Thesis, Wroclaw University of Science and Technology, Wroclaw, Poland, 2010. (In Polish).

23. Cała, M.; Flisiak, J.; Tajduś, A. Mechanism of Engagement between Bolts and Rock Mass of Various Formation; Library of Undergr. Min. School: Krakow, Poland, 2001. (In Polish)

24. Collaborative Publication. Instructions on Determining the Geomechanical Parameters of Roof Rocks with Respect to Roof Classes in Copper Mines, as Required in the Selection of a Roof Bolt System Design; KGHM Polska Miedz S.A.: Lubin, Poland, 2017. (In Polish)

25. Collaborative Publication. Regulations on the Selection, Construction and Control of Excavation Support in the KGHM Polska Miedz S.A. Mines; KGHM Polska Miedz S.A.: Lubin, Poland, 2017. (In Polish)

26. Pawelus, D. Stability assessment of headings situated in a field of high horizontal stress in Polish copper mines by means of numerical methods. In IOP Conference Series_Earth E Environmental Science, Proceedings of the World Multidisciplinary Earth Sciences Symposium, Prague, Czech Republic, 3-7 September 2018; IOP Publishing Ltd.: Bristol, UK, 2019; Volume 221, p. 221.

27. Pawelus, D. The azimuths difference method as an effective method of determining the value of horizontal stress acting on mining excavations in underground mines. In Science and Technologies in Geology, Exploration and Mining 1.3, Exploration and Mining, Proceedings of the 18th International Multidisciplinary Scientific GeoConference, Albena, Bulgaria, 2-8 July 2018; Curran Associates, Inc.: New York, NY, USA, 2018; Volume 18, p. 18.

28. Amadei, B.; Stephansson, O. Rock Stress and Its Measurement; Chapman \& Hall: London, UK, 2009.

29. Hoek, E.; Carranza-Torres, C.T.; Corkum, B. Hoek-Brown failure criterion-2002 edition. In Proceedings of the North American Rock Mechanics Society Meeting, Toronto, ON, Canada, 7-10 July 2002.

30. Hoek, E. Strength of rock and rock masses. ISRM News J. 1994, 2, 4-16.

31. Hoek, E.; Brown, E.T. Practical estimates of rock mass strength. Int. J. Rock Mech. Min. Sci. 1997, 34, 1165-1186. [CrossRef]

32. Hoek, E.; Marinos, P. GSI: A geologically friendly tool for rock mass strength estimation. In Proceedings of the ISRM International Symposium, Melbourne, Australia, 19-24 November 2000. 